\title{
Influence of the Addition of the Essential Oil of Cinnamon (Cinnamomum burmanii) in Soap Against Skin Care
}

\section{Dwi Atmanto}

Cosmetology Vocational Education Study Program, Faculty of Engineering, State University of Jakarta, Rawamangun Muka St, East Jakarta Indonesia

\section{Abstract}

Cinnamon contains the compound eugenol $3.11 \%$ and cinnamaldehyde $(90.24 \%)$ and coumarin (53.46\%), which can reduce acne blemishes on an oily face and have a thinning effect on stain and acne busting speed. In addition, cinnamon also contains vitamin $C$ that plays and protects the skin from UV rays from bad influences that cause premature aging and prevent the formation of melanin. Cinnamon can be processed into oil through distillation. The Cinnamon essential oil can be mixed in cosmetic products such as herbal soap and utilized for skin care. For this research, the herbal

Corresponding Author: Dwi Atmanto

dwi_atmanto@yahoo.com

Received: 11 January 2019

Accepted: 14 February 2019

Published: 25 March 2019

Publishing services provided by Knowledge E

(c) Dwi Atmanto. This article is distributed under the terms of the Creative Commons

Attribution License, which permits unrestricted use and redistribution provided that the original author and source are credited.

Selection and Peer-review under the responsibility of the 3rd ICTVET 2018 Conference Committee.

\section{S OPEN ACCESS} soap was developed with a mixture of cinnamon oil. The process began from the preparation of materials by processing Cinnamon Bark essential oil into cinnamon and mixing with essential oils in the formula herbal soap to become a soap product. Soap herb blend of cinnamon oil can be used to clean the face and it helps in removing the stain of acne scars. The research sample includes 10 people, divided into two groups, the experimental group using the soap mixed with essential oils and a control group with treatment using the facial Soap. Each skin care treatment consists of as much as eight treatments. The results showed that there is an influence of soap mixed with essential oils against the decline in the growth of acne scars dark flecks.

Keywords: distillation, cinnamon oil, soap, acne scars, flecks of acne scars

\section{Introduction}

Indonesia is one of the largest cinnamon producers that supplies most of the world's international markets. Cinnamomum (Cinnamommum burmannii) including Lauraceous family, Cinnamomum clan which consists of hundreds of species in Asia and Australia, one of which is Cinnamomum burmanii, which is widely cultivated in Indonesia. Cinnamon is known as one type of spice oldest in the world. Cinnamon bark, branches and branches can be used as spices and are one of Indonesia's export commodities. From the phytochemical aspect of cinnamon has almost all of the parts of the plant containing essential oils with different compositions, the cinnamon leaves also contain 
essential oils which are potential enough to be utilized. The use of cinnamon leaves is an effort to optimize the benefits of a type of plant. In addition to extracts, cinnamon leaves are also used through leaf distillation to obtain cinnamon leaf essential oil.

Of the total 28,000 species of medicinal plants in Indonesia, 1,845 have been identified as drug-like properties, and there are 283 active species explored by the compounds [2]. Some types of plants can be processed in advance to produce oil with a distinctive aroma and can be used directly or by derivative products. This oil is called essential oil which is currently in the spotlight of the body care industry because it is not only able to nourish the skin well, but also ultrasonic, fast and easily absorbed.

Market demand for essential oils both domestically and abroad is increasing. In accordance with export data from the Ministry of Industry of the Republic of Indonesia, the export of cinnamon (Cinnamon and cinnamon-tree flowers, crushed or ground) has a trend of $18.65 \%$ while exports of essential oils (essential oil of lemon grass, citronella, nutmeg, cinnamon, ginger) have $10.98 \%$ trend. Domestic food, pharmaceutical and cosmetics industries are markets for essential oils or essential oil derivatives. Essential oil is needed as a raw material for the cosmetics industry, body care products, health and food.

Benefits of Cinnamon [12] are; 1). Cinnamon bark is a type of spice that is widely used as a flavoring and flavoring ingredient in food and beverages, and additives in the manufacture of perfumes and medicines, 2). Cinnamon which consists of eugenol and cinnamaldehyde, has the power to kill microorganisms as an anti-microbial. In experiments in a lab, cinnamon oil is able to kill rickettsia (microorganisms in the form of bacteria but are like viruses, causes of typhus disease) within 12 minutes.

The efficacy of these drugs is inseparable from the activities of chemical components contained in these plants namely essential oils, eugenol, safrole, cinnamaldehyde, tannins, calcium oxalate, resin, and tanners. Its chemical, spicy, slightly sweet, warm and fragrant. The main value of cinnamon is in the skin of the stems, branches and twigs that contain essential oils, especially cinnamaldehyde (60-75\%) and eugenol (418\%) [13].

Cinnamon contains compounds that function as anti-oxidants. Antioxidants are compounds that can delay, inhibit, or prevent the oxidation process in food so it does not cause rancidity / damage [1]. One chemical component in cinnamon bark is a pale yellow oil-like liquid produced from extracting essential oils such as oil from cloves and cinnamon [6]. Eugenol has the molecular formula $\mathrm{C}_{10} \mathrm{H}_{12} \mathrm{O}_{2}$, and dissolves in alcohol, ether and chloroform. Eugenol is widely used in pharmaceuticals, food and beverage industry, cosmetics and as a raw material for other chemical products. Essential oils 
obtained from Cinnamomum zeylanicum leaves are rich in eugenol, which is 65-95\% which is an important ingredient in the industry of essence.

In addition, cinnamon oil can be used in industrial fields such as mouthwash and pasta, fresheners of soap, detergents, lotions, perfumes and creams. Eugenol is a monohydroxy or phenol cyclic alcohol so it can react with strong bases. Eugenol is volatile colorless or slightly yellow in color and has a bitter taste [3]. Eugenol is used as a perfume raw material, flavoring agent, and in the field of medicine as an antiseptic and anesthetic. Eugenol is also used in the manufacture of isoeugenol to produce synthetic vanillin [8]. The name IUPAC Eugenol is 4-Alil-2- methoxyphenol; Other names, many of which are: 2-Metosi-4- (2-propenyl) phenol, Eugenic Acid, Kariophylic Acid, 1-Alyl3-methoxy-4-hydroxybenzene, Alilguaiacol, 2-Methoxy-4-Allyphenol, 4- Allyckatecol-2methyl ether, 2-methoxy-4- (2-propen-1-il) phenol [4].

TABLE 1: Chemical Composition of Cinnamomum burmanni [12].

\begin{tabular}{l|c}
\hline Characteristics & Composition \\
\hline Water content & $7,9 \%$ \\
\hline Essential oil & $3,4 \%$ \\
\hline Alcohol Extract & $8,2 \%$ \\
\hline Ash & $4,5 \%$ \\
\hline Water soluble ash & $2,23 \%$ \\
\hline Ash is not water soluble & $0,013 \%$ \\
\hline Coarse fiber & $29,1 \%$ \\
\hline Carbohydrate & $23,3 \%$ \\
\hline Ether extract that does not fly & $4,2 \%$ (non-volatile) \\
\hline Nitrogen & $0,66 \%$ \\
\hline Average BJ & $1,02-1,07$
\end{tabular}

The use of cosmetics is now increasingly widespread, one of which is the oldest cleansing cosmetics since centuries ago. Soap is one of the most important and necessary products in everyday life which is a cleaning agent that can be used with water to clean and wash every day.

One of the toiletries that must be in the bathroom is soap. Almost everyone must use soap, especially facial soap and of course it takes healthy soap and has a good content and can provide skin care and also has an affordable price. These soaps can contain essential oils which of course have very good properties. Aside from being an antibacterial it can also remove spots or acne scars on the face. At present there are still many people who choose cosmetics from endangering the skin and having very good properties [16]. One herbal product that is currently being used is herbal soap that has other properties for the skin, especially the face, in addition to cleaning from 
dirt. The face requires special soap that can overcome problems such as acne, facial spots, or facial moisture problems.

Disorders of the skin such as acne problems are very disturbing appearance and is a disease or inflammation that affects the pilosebaceous composition of the skin which often leaves black stains or black spots which is certainly very disturbing appearance. For this reason, a product face can be used for a long time and can treat acne and disguise black spots or on the face. The product is in the form of herbal facial soap that uses natural ingredients as raw materials such as coconut oil and cinnamon essential oil.

1. For bases / alkalis used in making soap are chemicals in the form of $\mathrm{NaOH}$ (Sodium or Sodium hydroxide) or $\mathrm{KOH}$ (Potassium or Potassium Hydroxide) which are strong ( $\mathrm{pH}$ above 10). This chemical is hygroscopic (easily absorbs water and corrosive (causes rust). Therefore the use of this material is in need of special attention because it is quite dangerous especially if it is directly in contact with the skin.

2. The results of the reaction between fatty acids with $\mathrm{NaOH}$ and $\mathrm{KOH}$ are different. If you use $\mathrm{NaOH}$, you will get a hard-texture soap, commonly known as solid soap or bar soap. If using $\mathrm{KOH}$ will produce liquid soap / cream, depending on the level of dilution used. In this study $\mathrm{NaOH}$ will be used to make herbal soap in solid form.

3. In addition to the above ingredients, alcohol is also needed to dissolve $\mathrm{NaOH}$, an additive in the form of cinnamon essential oil and granulated sugar in addition to making transparent solid soap which serves to help form transparency in soap (Hambali, 2005). Transparent solid soap is soap the shower is shaped like a bar with a transparent appearance, resulting in softer foam on the skin and more shiny appearance than other types of soap so it looks more attractive [9].

\section{Methods and Equipment}

Samples were taken by purposive sampling, namely samples that have certain conditions, namely women aged 30 - 45 years, and have dry facial skin and mild black spots Field workers, do not use contraceptives, such as birth control pills or injections, are not in medical care or treatment beauty experts with regard to dryness and black spots on the skin of the face.

Samples were taken as many as 10 facial skins, which were divided into 2 groups, namely 5 facial skins treated with Cinnamon Soap and the rest were treated with mask control. All samples were treated 8 times for 1 month. 
Cinnamon soap is made by means of a saponification process that has been washed and then the results of the soap are applied to the face of the sample which has been coated with gauze. Soap is applied to the face for 5-10 minutes. The results showed that there were essential oils in the soap and curcuminoid compounds which could reduce mild black spots and moisturize dry skin. Before and after treatment the samples were measured on black spots on the face with an Analyze Skin Pigmentation instrument as an instrument of this study.

\section{Results}

TABLE 2: Description of Research Results Data in Research Group.

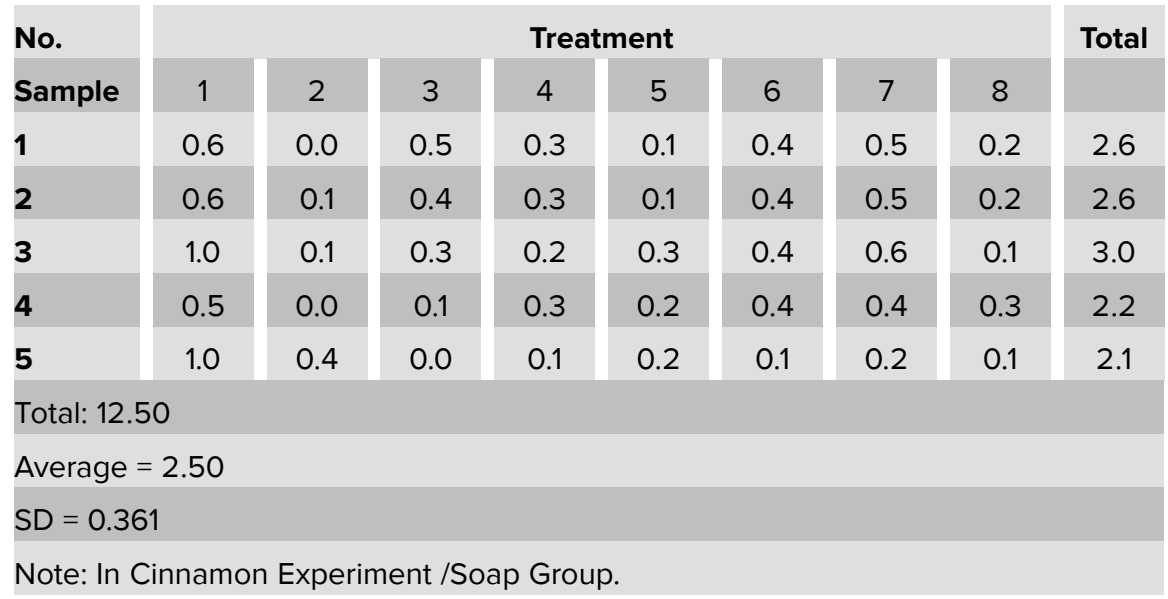

TABLE 3: Description of Research Results Data in the Control Group.

\begin{tabular}{|c|c|c|c|c|c|c|c|c|c|}
\hline \multirow{2}{*}{$\begin{array}{l}\text { No. } \\
\text { Sample }\end{array}$} & \multicolumn{8}{|c|}{ Treatment } & \multirow[t]{2}{*}{ Total } \\
\hline & 1 & 2 & 3 & 4 & 5 & 6 & 7 & 8 & \\
\hline 1 & 0.0 & 0.2 & 0.1 & 0.2 & 0.0 & 0.2 & 0.2 & 0.0 & 0.9 \\
\hline 2 & 0.0 & 0.0 & 0.0 & 0.1 & 0.0 & 0.4 & 0.2 & 0.1 & 0.8 \\
\hline 3 & 0.1 & 0.1 & 0.3 & 0.1 & 0.0 & 0.2 & 0.3 & 0.0 & 1.1 \\
\hline 4 & 0.1 & 0.1 & 0.1 & 0.1 & 0.2 & 0.1 & 0.0 & 0.0 & 0.7 \\
\hline 5 & 0.2 & 0.0 & 0.1 & 0.1 & 0.2 & 0.0 & 0.1 & 0.1 & 0.8 \\
\hline \multicolumn{10}{|c|}{ Total: 4.30} \\
\hline \multicolumn{10}{|c|}{ Average $=0.023$} \\
\hline \multicolumn{10}{|c|}{$S D=0.152$} \\
\hline
\end{tabular}

Data from the reduction of Cinnamon soap group black face spots turned out to be $<\mathrm{L}_{\text {table }}$ : $0.197<=0.05$ is obtained $\mathrm{L}_{\text {table }}=0.337$, it turns out $\mathrm{Lo} \alpha 0.337$. So that the null hypothesis is accepted, meaning that the sample taken comes from a population that is normally distributed. As for the control mask Lo $=0.252$ with $n=5$, and the significant level is < Ltable is: $0.252<0.337$. So that the null hypothesis is accepted, meaning 
TABLE 4: Comparison of Research Result.

Variable
Sum of Subjects
Sum of Value
Average
Variance
Standard Deviation
The Highest Value
The smallest Value

\begin{tabular}{|c|}
\hline Cinnamon Soap \\
\hline 5 \\
12.50 \\
2.50 \\
0.13 \\
0.361 \\
3.0 \\
\hline 2.1 \\
\hline
\end{tabular}

\begin{tabular}{|c|}
\hline Control Masker \\
\hline 5 \\
\hline 4.30 \\
\hline 0.86 \\
\hline 0.023 \\
\hline 0.152 \\
1.10 \\
\hline 0.70 \\
\hline
\end{tabular}

that the sample taken comes from a population that is normally distributed. From the calculation results obtained $\mathrm{F}_{\text {count }}=5.65$. Located in the recipient area $\mathrm{Ho}$, namely: 0.16 $<5.65<6.39$, the results show that Ho is accepted and $\mathrm{H} 1$ is rejected so that it is concluded that the population of the group is homogeneous.

Based on the calculation results obtained $t_{\text {count }}>t_{\text {table }}$ is $9.375>1.86$, then $\mathrm{H}_{o}$ is rejected and $H_{1}$ is accepted at a significance level of 0.05 . So the conclusion is that there is an effect of using Cinnamon soap on reducing light black spots on a woman's dry skin 30 years and above.

\section{Discussion}
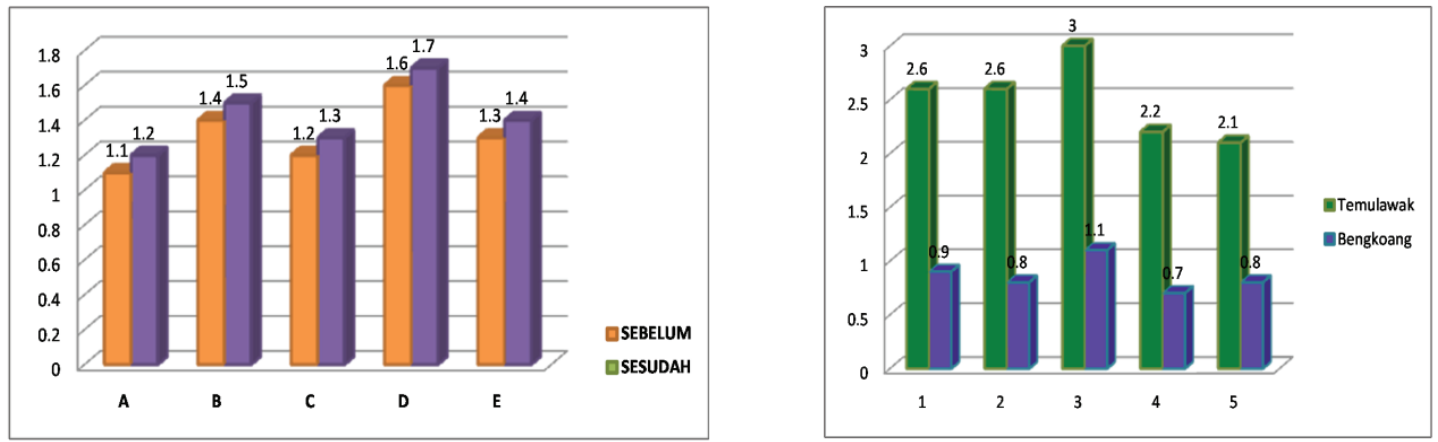

Figure 1: Graph of Average Value of Black Spots Reduction (a) Cinnamon Soap Group and Control Masker group.

Based on the results of the study, the two types of masks used, Cinnamon soap and control masks, have an effect on the reduction of dark black spots on the facial skin. However, based on the description above, it can be seen from the two masks used in this study (Cinnamon soap and control masks) which have the greatest influence on the reduction of mild black spots on the face is the use of Cinnamon soap. It is also based on research data that shows that from 1 to 8 treatments in all samples, the results of the reduction of mild black spots using Cinnamon soap are more influential than the 
control masks can be seen from Figure 1. Based on the results of the study, both soap and mask types used were Cinnamon soap and control masks which had an effect on the reduction of dark black spots on facial skin. However, based on the description above, it can be seen from the two masks used in this study (Cinnamon soap and control masks) which have the greatest influence on the reduction of mild black spots on the face is the use of Cinnamon soap.

Cinnamon has antibacterial properties, and is good for preventing skin problems such as hives and fungi [11]. Antibacterial components in cinnamon include oil volatile compounds containing cinnamaldehyde (cinnamaldehyde) compounds, and polyphenol compounds namely proanthocyanin (proanthocyanidin).

Cinnamon has an eugenol compound of 3.11\% and cinnamaldehyde $(90.24 \%)$ and coumarin (53.46\%) [7], which has been shown to reduce acne stains on oily facial skin and affect thinning, stain area and speed of acne removal [10]. Besides cinnamon also contains vitamin $\mathrm{C}$ which acts to protect the skin from the effects of bad UV rays that cause premature aging and prevent the formation of melanin [15].

Cinnamon is also rich in antioxidants that can slow down the aging process. Besides that cinnamon also contains lots of vitamins and minerals that are good for skin and hair health. Cinnamon has the effect of blood circulation to reach the hair roots to stimulate hair growth.

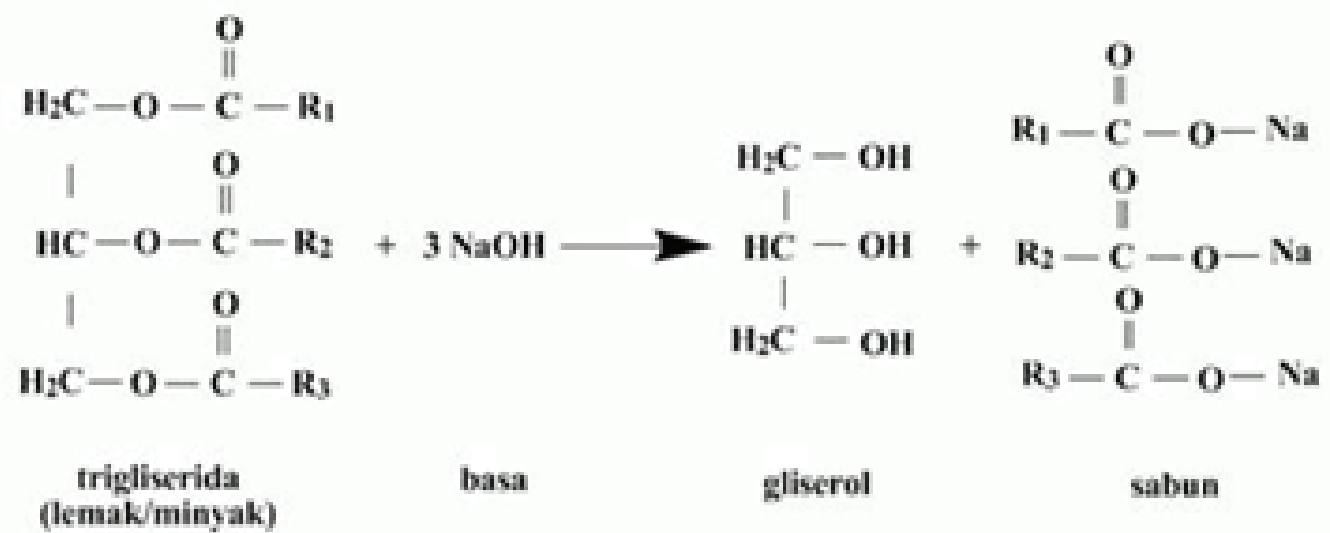

Figure 2: Saponification Reaction for Soap Product [14].

In the manufacture of soap, the type of acid used is fatty acids, both animal and vegetable. These fatty acids are generally categorized as weak acids such as frying oil, coconut oil, palm oil, castor oil (Ricinus oil), beef fat, lard, and others. So oil is a natural ingredient in making soap. 


\section{Conclusion}

Based on the results of the study, it can be concluded that the use of Cinnamon soap affects the reduction of mild black spots on the treatment of dry facial skin in line with the results of hypothesis testing $(\mathrm{Ho})$ which is done using $t$-test. Based on the calculation results obtained $\mathrm{t}_{\text {count }}>$ ttable is $9.375>1.86$, then $\mathrm{Ho}$ is rejected and $\mathrm{H} 1$ is accepted at a significance level of 0.05 with $\mathrm{df}$ is $\mathbf{8}$. So, there is an effect of using Cinnamon soap (Cinnamomum burmanii) on reducing black spots on the skin dry face.

\section{Funding}

This research was funded by the BLU funds from the Faculty of Engineering, Jakarta State University.

\section{Acknowledgment}

The researchers express their gratitude and appreciation to the students involved in the research and fellow lecturers who had provided input for the perfection of the research results.

\section{References}

[1] Barlow. 1989. Toxicological Aspect of Antioxidants Used as Food Additives. Elsevier Applied Science, London.

[2] Bahtera, Eka. 2015. Terbesar Kedua di Dunia, Keanekaragaman Hayati Indonesia Baru Tergarap 5\%. (dikunjungi: 30 September 2018 dari http://news.unpad.ac.id/?p= 36173

[3] Guenther, E. 1987. Minyak Atsiri jilid I (Terjemahan). Jakarta: UI Press.

[4] Gülcin, Ilhami. 2012, Antioxidant Activity of food constituent: an overview, Arch Toxicol, 86(3), pp. 345-391.

[5] Hambali, E., Suryani, A. \& Rifai M. 2005. Membuat Sabun Transparan untuk Gift dan Kecantikan. Jakarta: Penebar Swadaya.

[6] Hamid AA, et al. 2011. Essential Oils: Its Medicinal and Pharmacological Uses. Int J Cur Res, 33: 086-098. 
[7] Hapsari, Yatri dan Partomuan Simanjuntak. 2010. Study Senyawa Kimia dalam Fase Ekstrak Etil Asetat Simplisia Cinnamomum spp. Secara KCKT dan KG-SM. Jurnal Kimia, Vol. 8 (http://http://jurnal.kimia.fmipa.unmul.ac.id/index.php/JKM/article/view/78, diakses 01 November 2017).

[8] Kumar, Ravendra, et al. (2012). A Review on the Vanillin Derivatives Showing Various Biological Activities. International Journal of PharmTech Research CODEN (USA),Vol. 4, No. 1, pp. 266-279, Jan-Mar 2012.

[9] Qisti, Rachmiati. 2009. Sifat Kimia Sabun Transparan dengan Penambahan Madu pada Konsentrasi yang Berbeda. Skripsi. Bogor: IPB.

[10] Rahayu, Debrina Ika 2013. Pengaruh Penambahan Berbagai Komposisi Kayumanis dan Madu dalam Pembuatan Acne Lotion Terhadap Penyamaran Noda Jerawat pada Kulit Wajah Berminyak. E-Jurnal UNESA, Vol. 02 No. 03 Tahun 2013.

[11] Repi, Noviano B, et.al, 2016. Uji Antibakteri Ekstrak Kulit Kayu Manis terhadap E. Coli dan S. Pyogenes. Jurnal e-Biomedik, Vol. 4, No.1 January-June 2016.

[12] Rismunandar. 2001. Kayu Manis Budidaya \& Pengolahannya. PT. Penebar Swadaya, Depok.

[13] Suherdi. 1999. Kajian Produksi Kulit Kayu Manis Dari Berbagai Tempat Di Sumatera Barat. Prosiding seminar penelitian tanaman rempah dan obat Sub Balitto Solok.

[14] Spitz, Luis. 1996. Soap and Detergent Theoritical and Practical Review. AOCS Press. United States of America.

[15] Trenggano and Fatma Latifah. 2007. Buku Pegangan IImu Pengetahuan Kosmetik. $\checkmark$ Editor: Joshita Djajadisastra. Jakarta: Penerbit Pustaka Utama.

[16] Ulaen, Selvi P.J, Yos Banne, Ririm A. Suatan. 2012. Pembuatan Salep Anti Jerawat dari Ekstrak Rimpang Temulawak (Curcuma xanthorrhiza Roxb). Jurnal IImiah Farmasi, Vol. 3, No. 2 (2012), Politeknik Kesehatan Kemenkes Manado. 